from comparable lengths of outcrop in France and England respectively, and it behoves those upon whom the duty falls of laying down the line of the tunnel, to take these probabilities into account." Generally speaking, Prof. Kendall seemed to think that there are more difficulties than had been assumed by most of his predecessors, but that they are not unsurmountable, and in any case he is strongly opposed to the suggestion that a tunnel might be made in the Gault under the chalk. This paper will appear in extenso in the Naturalist.

Afterwards the chairman, Dr. Bather, addressed the delegates as to the value of their annual conference and asked for opinions to be expressed with regard to its future working. He called upon Mr. T. Sheppard, the vice-chairman of the Corresponding Societies' Committee, who has been associated with the Conference for many years, to give his views on the matter, after which many of the delegates spoke.

At the final session of the French Association, under the presidency of General Perrier, medals which had been specially struck were presented to those who had been conspicuous in assisting the Congress, the names of the recipients being in relief. Sir Henry Lyons, director of the Science Museum, London, and Mr. T. Sheppard, who acted as local secretary for the Havre meeting on behalf of the British Association, each received one of these medals.

At the concluding banquet, held at the Hotel Frascati, representatives of the different countries sending delegates were 'toasted ', and members from Belgium, Portugal, Spain, and Great Britain each spoke in turn, Mr. Sheppard representing the British Association.

\section{Welsh Bygones.}

$\mathrm{T} N$ view of the plea for the institution of a national folk-museum for England which appeared in NATURE of Aug. 24, p. 289, it may not be out of place to describe here briefly what has already been done in the National Museum of Wales at Cardiff on similar lines to preserve the evidences of the arts and industries of the Welsh people in post-Reformation times.

The collections for the most part are at present housed temporarily in a gallery which was specially built for the purpose in 1925; but adequate and permanent accommodation will be available when the eastern range of galleries now in course of erection is completed. At the moment 1294 objects are actually on exhibition, but a number are still in store. The exhibits cover a very wide range; and they also include a certain amount of material from England and Ireland. This has been judged necessary not only for purposes of comparison, but also because England for centuries has supplied Wales with such articles as her pottery and most of her cutlery. Many of the articles are dated, and thus, in illustrating the history of the arts and crafts in Wales, they also provide a basis for a systematic chronology for Welsh bygones.

The arrangement of the exhibits has been carried out so far as possible with due regard to their original purpose, but the limited space available makes complete logical arrangement difficult and in some cases impossible. So far as may be, groups have been kept together. Thus, on passing from the entrance hall of the Museum, where are the Eisteddfod chairs, the stocks, pottery, folklore objects and other exhibits of special interest, the first cases in the Bygones Gallery contains kitchen appliances, followed by table ware and then laundry appliances. Then comes a block of exhibits showing dairy appliances and agricultural implements. These are succeeded by the implements and appliances of various industries, such as mining, spinning and weaving, lacemaking and knitting, trapping and fishing and transport. Then follow exhibits relating to the horse and the various crafts. Furniture, costumes and personal ornaments, important sections, necessarily occupy a considerable amount of space. The ecclesiastical, economic, and social life are well illustrated by a varied and wide range of objects. Dress, in particular, includes a valuable collection of richly ornamented eighteenth-century costumes from Tredegar Park. These, of course, are additional to the well - represented peasants' costumes. Objects related to the Eisteddfod naturally figure largely. They include manuscripts, Druid's chairs, and the 'wooden book'-squared wooden sticks in a frame, invented by the Glamorgan druids-harps, etc., and other musical instruments.

Among the objects illustrative of Welsh folklore are rags from wishing wells and a large and valuable collection of 'love-spoons'. The 'love spoon', it may be explained, was a carved wooden spoon which was presented by the lover to the object of his affections. Originally it was merely a wooden copy of a metal spoon, but it became highly elaborated. Another folklore object of great interest which the Museum is fortunate enough to possess is a "Mari Llwyd' from Llangwynyd, Glamorgan. The 'Mari Llwyd ' corresponds to the "hooden horse' of 'Thanet and elsewhere. The 'Mari Llwyd', like the 'hooden horse ', is a horse's skull and jaws sheeted and adorned with coloured ribbon, streamers, etc. The sheet completely covered a man who carried it at the head of a procession at the Christmas and New Year festivities. In Wales its use was afterwards transferred to May Day. It would be out of place to discuss its origin and meaning here; but though the authorities of the National Museum accept the derivation that it was a substitute for the ass of the medieval miracle and mystery plays, it is more probably a fertility symbol of much older date.

Owing to considerations of space, the collections with two exceptions have to be exhibited under museum conditions, that is, in cases and on walls. The exceptions are the kitchen and bedroom furniture and appliances. Two recesses in the galleries have been utilised to give these objects their natural setting in a typical Welsh kitchen and a typical Welsh bedroom. Here are the fireplace, turnspit, cooking utensils, dressers with crockery, clocks, chairs, etc., the bed, mattress and bedding, the coffer, press, Bible and deed boxes, candles and so forth, in the conditions in which they were actually in use.

A well-illustrated guide to the collections, with an introductory account of Welsh life and culture by Mr. Iorwerth C. Peate, assistant curator, has recently been published by the National Museum of Wales, Cardiff (price 1s. 6d.).

\section{University and Educational Intelligence.}

CAmbridge.-The Appointments Committee of the Faculty of Agriculture and Forestry has appointed Mr. F. H. Garner, of Clare College, to be University lecturer in agriculture, and Mr. A. S. Watt to be University lecturer (Gurney lecturer) in forestry.

The following University lecturers have resigned their offices: Mr. P. Sergeant Florence, Caius (economics); Mr. S. Lees, St. John's (engineering); Mr. R. V. Southwell, Trinity (mathematics); Dr. D. R. Hartree, St. John's (physics); Mr. A. Amos, Downing (agriculture); Mr. R. L. Manning, Jesus (geography). 
Mr. W. S. Mansfield, Emmanuel, has been appointed Director of the University Farm.

An industrial bursary has been awarded by the Royal Commissioners for the Exhibition of 1851 to Mr. H. V. Rose, Jesus College, to enable hir to undertake an apprenticeship with the British ThomsonHouston Company, Limited.

The Trustees of the Busk Studentship in Aeronautics have awarded the studentship for the year 1929-30 to Mr. S. G. Hooker, of the Royal College of Science, London.

The City and Guilds of London Institute's report for 1928 shows a further small decrease in the number of students in the City and Guilds (Engineering) College, which reached its maximum in 1921-22. Since that date there has been a continuous decline in the enrolments in the mechanical engineering and motive power department, and this has been only partially counterbalanced by an increase in the electrical engineering department. The number of students from India (28) has increased largely in the past two years. A noteworthy event of the year was the establishment of a Maybury chair of highway engineering as a result of an offer made by a joint committee of the Paviors' Company and of the Institution of Municipal and County Engineers. The Institute's Department of Technology reports an increase in the number of candidates examined from 14,205 to 16,048 , including an increase in the number of those examined at centres overseas from 1788 , the previous maximum, to 1878 . The new scheme of handicraft examinations (metal and woodwork) lately brought into force led to the entry of more than double the former number of candidates for the First, while the entries for the Second Handicraft Examination, held for the last time under the old scheme, also nearly doubled.

THE report of the United States Commissioner of Education for the vear 1927-28 (Washington, D.C. : Government Printing Office, pp. 42, price 5 cents) is by Dr. J. J. Tigert, an old Rhodes scholar, who held the office of Commissioner for the seven years 1921-28. It comprises (1) a review of recent events in public education, and (2) a report on the work of the Bureau of Education, of which the Commissioner is the head. In the field of higher education, prominence is given to a recent judicial decision declaring to be unconstitutional an act of the legislature of the State of Minnesota which would have usurped the rights and powers of the governing body (Board of Regents) of the University of Minnesota. This decision ensures a professional rather than a political development of the educational policies of the University. Attention is also directed to events indicative of "an awakened consciousness of the supreme value of the library in modern methods of college instruction ", of increasing systematisation of research and graduate work, and a tendency towards the affiliation of small or junior colleges with larger institutions or with groups. Investigations have shown anew the neglect of the teaching of physiology and hygiene in secondary schools and colleges. There has been a steady increase, however, in the number of high schools giving instruction in sex hygiene, the tendency being to make it a part of more general courses, such as biology or physiology, and to give less emphasis to disease. The Bureau's work is essentially an intelligence service, and in no country in the world is education better served in this respect. The list of educational researches and surveys by its staff is impressive. Its library division maintains useful bibliographies, indexed and cross-referenced, of research studies in education throughout the United States.

\section{Calendar of Patent Records.}

September I, I 585. - The patent granted by Queen Elizabeth to Thomas Wilkes for twenty-one years on Sept. 1, 1585, for the manufacture and importation of salt, which conferred on the patentee a virtual monopoly of the salt trade on the east coast of England, was one of the chief grievances raised in the monopoly debates in the Parliament of 1601. In spite of the terms of the grant, which provided for an adequate supply of salt at a cost not exceeding that prevailing in London, John Smith, to whom the patent was assigned in 1599, raised the price from 14 pence to 14 shillings a bushel, and thus provided a case for the House of Commons that could not be ignored. The patent was voided with other similar grants by Royal Proclamation.

September 3, r 893.--Otto Lilienthal, an aeronautical pioneer to whose enthusiasm and perseverance the successful evolution of the aeroplane owes a great deal, patented his glider machine in Germany on Sept. 3, 1893. Lilienthal made more than two thousand attempts at flight with his various machines, and finally succeeded in gliding for distances of 200-300 yards. In his earliest gliders, stability was obtained by movements of his own body, but later he added steering gear to the machine, and it was while experimenting with this in the air in 1896 that he met his death.

September 4, I $84 \mathrm{I}$.- The chain-grate mechanical stoker, practically in the form in which it is known to-day, was introduced by John Juckes, who obtained an English patent for the invention on Sept. 4, 1841. The first installation was erected the following year at the works of Messrs. Easton and Amos in Southwark, and not only showed a saving in the consumption of coal of about 10 per cent, but also, by enabling a poorer quality of fuel to be used, permitted a still greater reduction in the cost. Though the invention was extensively adopted, Juckes died in poverty. (Cf. Calendar of Patent Records, May 24.)

September 5, 1877.- The successful application of compressed air for working a system of secondary clocks from a standard clock was the invention of the Viennese engineer, Carl Albert Mayrhofer, who applied for his German patent on Sept. 5, 1877. In his earliest arrangements, the controlled clocks received impulses, through small leather bellows, once every minute from the standard clock, but in later forms they had ordinary going trains, and the positions of the hands were corrected and the main springs re-wound at set hours. The invention attracted a good deal of notice at the Paris Exhibition of 1878, and the systems were installed in public buildings in Vienna and Berlin, and on a larger scale in the streets and shops of Paris.

September 6, I831.- The 'miners' safety fuse' of William Bickford was patented on Sept. 6, 1831. The fuse was almost at once adopted by the British Government for military purposes, and by the mining industry, and resulted in a very large reduction in the number of blasting accidents.

September 6, I 834.- Of the many inventions made by General Henry Shrapnel, the best known is the artillery shell to which his name has been given. Shrapnel shell was first used at the capture of Surinam in 1804, and its success was immediate, the range being four or five times that of the case-shot which it replaced. No patent was taken out for the invention, but Shrapnel received an annuity of $£ 1200$ from the Government and one of $£ 20^{\circ} 0$ from the East India Company, and would have received a baronetcy if William IV. had not died before he could confer it. Shrapnel's only patent is dated Sept. 6, 1834, for improvements in the sighting apparatus and other parts of fire-arms. 